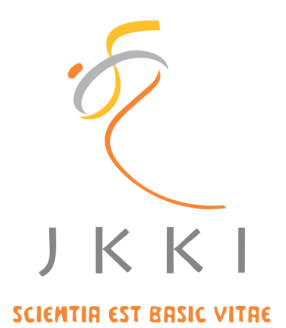

Jurnal Kedokteran dan Kesehatan Indonesia

Indonesian Journal of Medicine and Health

Journal homepage: https://journal.uii.ac.id/JKKI

\title{
Assessments of quality of life in burn patients after hospital treatment in Jember
}

Agnellia Maulidya Utami ${ }^{1}$, Ulfa Elfiah*2, Desie Dwi Wisudanti ${ }^{3}$

${ }^{1}$ Faculty of Medicine, Universitas Jember, Jember, Indonesia

${ }^{2}$ Department of Plastic Surgery, Faculty of Medicine, Universitas Jember, Jember, Indonesia

${ }^{3}$ Departement of Pharmacology, Faculty of Medicine, Universitas Jember, Jember, Indonesia

Original Article

\begin{tabular}{l}
\hline \\
\hline ART ICLE I NF O \\
\hline Keywords: \\
Lengths of hospital stay, \\
numbers of surgical procedures, \\
burn severity, \\
QoL, \\
SF-36 \\
\hline *Corresponding author: \\
ulfa.fk@unej.ac.id \\
\hline DOI:10.20885/JKKI.Vol11.Iss2.art8 \\
\hline History: \\
Received: January 30, 2019 \\
Accepted: July 23, 2020 \\
Online: August 31, 2020 \\
\hline Copyright @2020 Authors. \\
This is an open access article \\
distributed under the terms \\
of the Creative Commons At- \\
tribution-NonCommercial 4.0 \\
International Licence (http:// \\
creativecommons.org/licences/ \\
by-nc/4.0/).
\end{tabular}

\section{ABSTRACT}

Background: Burn injuries can contribute to physical and psychological problems affecting quality of life (QoL). The QoL is a parameter to assess medical results after treatment. In Indonesia, studies concerning burn patients' QoL after treatment are still limited.

Objective: This study aims to observe correlations between 8 dimensions of QoL after treatment and histories of burn severity, numbers of surgical procedures, and lengths of hospital stay

Methods: A cross sectional study was conducted in December 2018. Subject criteria of this study were patients who have experienced burn injuries for the last 2 years and have been treated at dr. Soebandi Hospital Jember. Then all the patients were discharged from the hospital by following medical advice in recovered conditions. They were asked to complete SF-36 questionnaires that consist of 8 dimensions of QoL. Every dimension was correlated with histories of burn severity, numbers of surgical procedure, and lengths of hospital stay. Next, the obtained data were analysed by Pearson and Spearman.

Results: 13 subjects or patients were analysed. Most of them (38.5\%) were adults in a range of $41-50$ years old and were male (69.2\%). A bivariate analysis found a significant negative correlation between burn severity and QoL in physical functions, bodily pains, and mental health dimensions $(p=0.030, p=0.012, p=0.044)$. A significant negative correlation was also reported between numbers of surgical procedures and QoL in physical role dimensions $(p=0.047)$. Lengths of hospital stay had a significant negative correlation with physical functions and physical role dimensions $(\mathrm{p}=0.044, \mathrm{p}=0.031)$.

Conclusion: This study revealed significant correlations between burn severity, numbers of surgical procedures, length of hospital stay and the various dimensions of QoL. This study also provided data of QoL, so in the future burn centres can identify dimensions of QoL after burn injuries and can improve their burn management and patient care to improve their QoL. Latar Belakang: Luka bakar menyebabkan timbulnya keterbatasan fisik maupun psikologisyang berdampak terhadap kualitas hidup. Kualitas hidup merupakan salah satu parameter untuk menilai hasil terapi. Di Indonesia, penelitian mengenai kualitas hidup pasien luka bakar pasca perawatan masih sangat terbatas. Tujuan: Mengetahui korelasi antara 8 dimensi kualitas hidup pasca perawatan dengan riwayat keparahan luka bakar, jumlah tindakan operasi, dan lama rawat inap. 
Metode: Studi cross sectional dilakukan pada bulan Desember 2018. Subjek penelitian adalah pasien yang pernah mengalami luka bakar dalam 2 tahun terakhir dan telah dirawat di RSD dr. Soebandi Jember. Seluruh pasien keluar dari rumah sakit dalam kondisi membaik dan dengan persetujuan dokter. Subjek diminta untuk mengisi kuesioner SF-36 yang terdiri dari 8 dimensi kualitas hidup. Tiap dimensi akan dikorelasikan dengan riwayat keparahan luka bakar, jumlah tindakan operasi, dan lama rawat inap. Data diolah menggunakan uji Pearson dan Spearman.

Hasil: Sebanyak 13 data dianalisis. Mayoritas partisipan adalah orang dewasa (38.5\%) dengan rentang usia 41-50 tahun dengan jenis kelamin lakilaki (69.2\%). Analisis bivariat menunjukkan adanya korelasi yang signifikan antara keparahan luka bakar dengan kualitas hidup pada dimensi fungsi fisik, nyeri, dan kesehatan mental ( $p=0.030, p=0.012$, $p=0.044)$. Korelasi yang signifikan juga dilaporkan terjadi antara jumlah tindakan operasi dengan dimensi peran fisik ( $p=0.047)$ sedangkan lama rawat inap memiliki korelasi yang signifikan dengan dimensi fungsi fisik dan peran fisik dari kualitas hidup ( $p=0.044, p=0.031$ ).

Kesimpulan: Studi ini menunjukkan bahwa terdapat korelasi yang signifikan antara keparahan luka bakar, jumlah tindakan operasi, dan lama rawat inap dengan berbagai dimensi pada kualitas hidup. Studi ini menyediakan data kualitas hidup pasien luka bakar sehingga nantinya burn center dapat mengidentifikasi dimensi kualitas hidup yang mungkin terganggu akibat luka bakar serta burn center diharapkan dapat meningkatkan kualitas perawatan pasien luka bakar.

\section{INTRODUCTION}

Burn injuries are a common cause of death and disability, especially in countries with low and middle outcomes. ${ }^{1}$ According to World Health Organization (WHO), burns were accounted for 180.000 deaths annually. ${ }^{2}$ Burn prevalence in Indonesia was $0.7 \%$ according to ministry of health in $2013 .{ }^{3} 70$ burn patients were admitted to dr. Soebandi Hospital Jember during a period of 2014-2016. ${ }^{4}$

Burn injuries are associated with impairments and problems in physical and psychological health. The most common problems include contractures, hypertrophic scars, muscle wasting, pain, itching, depression and anxiety. These problems eventually affect burn patients' QoL (quality of life). ${ }^{5}$ Most of burn patients has been reported with impaired QoL. ${ }^{6}$ A study conducted on post-burn patients revealed that 1-15\% patients were wholly unable to return to work after burn injuries.7 After having burn injuries, not returning to work has been related to low QoL.

The QoL is a key indicator to assess medical results after medical treatments. Burn treatment depends on severity of the burns, and severe burns require a longer period to heal and need more treatment including plastic surgery. ${ }^{8}$ Treatments of the burn patients could be seen through the lengths of hospital stay and numbers of surgical procedures. Treatment given to the burn patients may have an important role in the patients' QoL. Some previous studies around the world have identified the burn patients' QoL after treatment and factors affecting it, but such studies concerning burn patients' QoL have been limited in Indonesia, especially in Jember Regency. The most frequently used assessment of generic QoL is SF-36. The SF-36 has been used in thousands of generics and specific population surveys, and it provides a valid measurement on recoveries of the patients QoL. ${ }^{9}$

Therefore, this study is purposed to assess correlations between burn patients' QoL after treatment and patients' histories of burn severity, numbers of surgical procedures and lengths of hospital stay.

\section{METHODS}

\section{Study design}

This study was a cross-sectional study. Its data were collected on December 2018 at patients' houses and at dr. Soebandi Hospital Jember, Jember, Indonesia.

\section{Subjects of study}

Subjects of this study were burn patients who have been treated at dr. Soebandi Hospital during a period of September 2016-September 2018. Its inclusion criteria were patients at age 18-60 years old, had experienced burn injuries in the past 2 years, stayed in Jember Regency and had completed medical record data. Its exclusion 
criteria were patients with chronic diseases and pre-burn psychiatric illness, patients with hospital discharge against medical advice, patients with unreachable address. Subjects as samples were collected by using a total sampling.

\section{Measurement}

In-home interviews with the patients were conducted. The QoL was measured by using the SF-36. The SF-36 was a self-report questionnaire with 36 questions consisting of 8 dimensions including general health, physical functions, physical roles, bodily pains, vitality, social functions, emotional roles, and mental health. Each dimension has range score from 0 (the worst QoL) to 100 (the best QoL) with cut-off point $>50$ indicating a better QoL. ${ }^{9}$ The patients were asked to fill in the SF-36 questionnaires to assess their QoL. Burn severity, numbers of surgical procedures, and lengths of hospital stay were measured by patients' medical records, and the burn severity was determined by American Burn Association criteria.

\section{Data analysis}

The obtained data was analysed by using the Pearson and Spearman test. P value $<0.05$ was considered as significant.

\section{Ethical clearance}

This study was approved by The Ethics Committee of Faculty of Medicine, Universitas Negeri Jember with an ethical clearance number 1.187/H25.1.11/KE/2018. Then informedconsent form was completed by the patients who become the subjects of this study.

\section{RESULTS \\ Characteristics of Subjects}

There were 48 cases with burn injuries treated at the dr. Soebandi Hospital for the last two years. Twenty patients met the inclusion criteria, but two patients had chronic diseases, three was discharged from hospital against medical advice and two patients could not be found; therefore, seven patients were excluded. As a result, the final samples consisted of 13 patients.

Based on the result, most of the patients (5 patients/38.5\%) were adult in a range of 41-50 years old. Male were dominant (9 patients/69.2\%). Among them, 8 patients (61.5\%) were employed. The socio-demographic characteristics of the patients can be seen in Table 1.

Table 1. Socio-demographic characteristics of the patients $(\mathrm{n}=13)$

\begin{tabular}{lcc}
\hline \multicolumn{1}{c}{ Variable } & $\begin{array}{c}\text { Frequency } \\
\text { (n) }\end{array}$ & $\begin{array}{c}\text { Percent } \\
\text { (\%) }\end{array}$ \\
\hline Age in categories (years) & & \\
$18-30$ & 3 & 23.1 \\
$31-40$ & 3 & 23.1 \\
$41-50$ & 5 & 38.5 \\
$51-60$ & 2 & 15.4 \\
Gender & & \\
Male & 9 & 69.2 \\
Female & 4 & 30.8 \\
Occupation & & \\
Employed & 8 & 61.5 \\
Unemployed & 5 & 38.5 \\
\hline
\end{tabular}


Table 2. Characteristic of patients according to the parameter of burn injuries $(n=13)$

\begin{tabular}{|c|c|c|}
\hline Variable & $\begin{array}{l}\text { Frequency } \\
\text { (n) }\end{array}$ & $\begin{array}{l}\text { Percent } \\
(\%)\end{array}$ \\
\hline \multicolumn{3}{|l|}{ Burn aetiology } \\
\hline Thermal & 6 & 46.2 \\
\hline Scald & 3 & 23.1 \\
\hline Electric & 2 & 15.4 \\
\hline Chemical & 2 & 15.4 \\
\hline \multicolumn{3}{|l|}{ TBSA burn } \\
\hline$<25 \%$ & 11 & 84.6 \\
\hline $25 \%-50 \%$ & 2 & 15.4 \\
\hline$>50 \%$ & 0 & 0 \\
\hline \multicolumn{3}{|l|}{ Depth of burn } \\
\hline $1^{\text {st }}$ degree (superficial thickness) & 0 & 0 \\
\hline $2^{\text {nd }}$ degree (partial thickness) & 11 & 84.6 \\
\hline $3^{\text {rd }}$ degree (full thickness) & 3 & 15.4 \\
\hline \multicolumn{3}{|l|}{ Burn severity } \\
\hline Mild ( 2 nd degree $<10 \%$ in adults; 2 nd degree $<5 \%$ in children; 3rd degree $<2 \%$ ) & 1 & 7.7 \\
\hline $\begin{array}{l}\text { Moderate (2nd degree } 10-20 \% \text { in adults; } 2 \text { nd degree } 5-10 \% \text { in children; } 3 \text { rd degree } \\
2-5 \% \text { ) }\end{array}$ & 4 & 30.8 \\
\hline $\begin{array}{l}\text { Severe ( } 2 \text { nd degree }>20 \% \text { in adults; } 2 \text { nd degree }>10 \% \text { in children; } 3 \text { rd degree } \\
>5 \% \text {, electrical injury; burn in face, hands, feet or genitalia area) }\end{array}$ & 8 & 61.5 \\
\hline \multicolumn{3}{|l|}{ Type of surgical procedure } \\
\hline Skin graft & 4 & 30.8 \\
\hline Skin flap & 1 & 7.7 \\
\hline Escharotomy & 1 & 7.7 \\
\hline Amputation & 1 & 7.7 \\
\hline \multicolumn{3}{|l|}{ Number of surgical procedure } \\
\hline No surgical procedure & 5 & 38.5 \\
\hline 1 times & 0 & 0 \\
\hline$>1$ times & 8 & 61.5 \\
\hline \multicolumn{3}{|l|}{ Length of hospital stay } \\
\hline$<15$ days & 7 & 53.8 \\
\hline$\geq 15$ days & 6 & 46.2 \\
\hline \multicolumn{3}{|l|}{ Complication } \\
\hline Hip albumin & 3 & 23.1 \\
\hline SIRS, Sepsis & 5 & 38.5 \\
\hline Anaemia & 2 & 15.4 \\
\hline \multicolumn{3}{|l|}{ Patients condition at hospital discharge } \\
\hline Burn remains $\leq 5 \%$ TBSA & 10 & 76.9 \\
\hline Burn remains $>5 \%$ TBSA & 3 & 23.1 \\
\hline
\end{tabular}


Table 2 shows characteristics of the patients according to parameters of burn injuries. A thermal burn was the most common cause of burn aetiology as many as 6 patients (46.2\%). Most of them (61.5\%) had severe burns. The most common surgical procedure was a skin graft including 4 patients (30.8\%). As many as 7 patients (53.8\%) had been hospitalized for less than 15 days, and 10 patients (76.9\%) had $\leq 5 \%$ TBSA left at the hospital discharge.
Average scores of every dimension in the SF-36 questionnaires were $>50$. It indicated that the QoL in burn patients after treatment was in good conditions. The most affected dimension of QoL was physical roles $(57.69 \pm 29.553)$ and the least affected dimension was social functions $(82.00 \pm 14.130)$. The average scores of every dimension in the SF-36 can be seen in Table 3.

Table 3. Average scores of eight dimensions in the SF-36 ( $\mathrm{n}=13)$

\begin{tabular}{lcc}
\hline \multicolumn{1}{c}{ SF-36 Dimensions } & Mean & SD \\
\hline General Health & 58.77 & 20.482 \\
Physical Function & 74.23 & 12.391 \\
Physical Role & 57.69 & 29.553 \\
Bodily Pain & 69.77 & 15.167 \\
Vitality & 71.15 & 17.578 \\
Social Function & 82.00 & 14.130 \\
Emotional Role & 71.92 & 23.009 \\
Mental Health & 74.15 & 13.502 \\
\hline
\end{tabular}

\section{Bivariate Analysis}

TThe bivariate correlation in Table 4 indicated that lengths of hospital stay had a significant negative correlation with the QoL in physical functions and role physical dimensions ( $\mathrm{p}=0.044$ and $p=0.031$ ). There was a significant negative correlation between burn severity and the QoL in physical functions, bodily pain, and mental health dimensions $(p=0.030, p=0.012$, and $\mathrm{p}=0.044$ ). Numbers of surgical procedures also had a significant negative correlation with role physical dimensions in QoL ( $\mathrm{p}=0.047)$.

Table 4. Bivariate correlation between QoL and lengths of hospital stay and burn severity

\begin{tabular}{lcccccc}
\hline \multirow{2}{*}{ SF-36 Dimensions } & \multicolumn{2}{c}{$\begin{array}{c}\text { Length of Hospital } \\
\text { Stay }\end{array}$} & \multicolumn{2}{c}{ Burn Severity } & \multicolumn{2}{c}{$\begin{array}{c}\text { Number } \\
\text { of surgical } \\
\text { procedure }\end{array}$} \\
\cline { 2 - 8 } & $\mathbf{r}$ & $\mathbf{p}$ & $\mathbf{r}$ & $\mathbf{p}$ & $\mathbf{r}$ & $\mathbf{p}$ \\
\hline General Health & -0.207 & 0.497 & 0.122 & 0.691 & -0.483 & 0.095 \\
Physical Functions & -0.565 & $0.044^{*}$ & -0.601 & $0.030^{*}$ & -0.490 & 0.089 \\
Physical Role & -0.599 & $0.031^{*}$ & -0.470 & 0.105 & -0.559 & $0.047^{*}$ \\
Bodily Pain & -0.106 & 0.792 & -0.671 & $0.012^{*}$ & -0.454 & 0.119 \\
Vitality & -0.387 & 0.191 & 0.089 & 0.773 & -0.439 & 0.133 \\
Social Function & -0.166 & 0.587 & -0.316 & 0.294 & -0.059 & -0.848 \\
Emotional Role & -0.179 & 0.179 & -0.382 & 0.198 & -0.289 & 0.338 \\
Mental Health & -0.056 & 0.856 & -0.565 & $0.044^{*}$ & -0.219 & 0.437 \\
\hline
\end{tabular}




\section{DISCUSSIONS}

A burn treatment plays an important role in patients' Quality of Life (QoL). Improved QoL in severe burn patients have been linked to effectiveness of the burn treatment including resuscitation, nutritional support, burn injury care, plastic surgery, and infection control. Thus, the burn treatment requires not only medical aspects but also psychological and social supports to improve the patients' QoL. Patients with severe burns who get adequate treatment will have better QoL. A successful treatment of burn patients will determine patients' condition at hospital discharge and also the patients' QoL.

In this study, sizes of burn injuries at the hospital discharge was $\leq 5 \%$ TBSA. This might cause the average scores of patients' QoL in all dimensions in this study were $>50$ meaning that the QoL in all dimensions was in good conditions. A relatively high score in burn patients' QoL suggested a successful burn treatment given to the patients at dr. Soebandi Hospital Jember. The burn treatment depended on the severity of the injury. Patients with severe burns would get more plastic surgery such as skin grafting. Skin grafting is required in the second degree or the third degree of burns to avoid formation of hypertrophic scars and keloid and to improve patients' QoL. ${ }^{10}$

Although treatment given to burn patients may contribute to improve the patient's QoL, a negative significant correlation was obtained between the numbers of surgical procedures and the physical role. Odoch et al. in his study found that surgical procedures had a significant relationship with lengths of hospital stay along with complications. All burn patients with complications such as anaemia, hip albumin, and sepsis will have longer lengths of hospital stay. ${ }^{11}$

This study also revealed a negative correlation between lengths of hospital stay and QoL in physical functions and role physical dimensions. The lengths of hospital stay were also related to the burn severity. Severe burn might need longer hospital stay. For burn patients, lengths of hospital stay estimation is one day per percent of total body surface of burn. ${ }^{12}$ Longer lengths of hospital stay related to lasting effects on weakness affecting patients' physical functions and QoL. Every day of bed rest could reduce muscle strength around $3 \%$ and $11 \% .^{13}$ During their treatment the patients might also experience hospitalization-associated disability. Hospitalization-associated disability is a disability to perform daily activities independently without any assistance. Hospitalization-associated disability developed during the hospitalization periods, but $29 \%$ patients remained disabled at 1 year after hospital discharge. ${ }^{4}$ Longer lengths of hospital stay can cause low back pain and contracture due to immobilization that impacts on patients' difficulties in physical activities and decreases QoL. ${ }^{15}$

A negative correlation was also found between the burn severity and QoL in physical functions, bodily pain, and mental health dimensions. Orwelius et al. and Wasiak et al. had reported similar findings. ${ }^{8,16}$ It might be because severe burns need longer period to heal and increase more scarring and disfigurement influencing the QoL negatively. ${ }^{16}$ Burns can change appearance either by scarring, pigmentation loss or disfigurement, and these have an effect on body imagea. ${ }^{17}$ Higher body image dissatisfaction is associated with a larger burn. One of the most common psychological problems caused by a burn injury is a negative impact on the body image that can lead to the decrease of QoL in mental health dimensions. ${ }^{18}$ Patients with severe burns may also experience depression. Depression is associated with physical and psychological dimensions in the QoL. ${ }^{19}$

Another consequence of the severe burn is muscle wasting, resulting reduced muscle strength. This leads to the patients' difficulty in physical activities and decreases the QoL. The severe burns have also correlated with chronic pain. They can cause axon to swell and induce peripheral nerve damages that may contribute to pain. Inflammatory responses induce release of mediators that stimulate and sensitize nociceptors. A previous study demonstrated that burns induced inflammatory responses persisted for 3 years after the burn injuries. ${ }^{20}$ 
This study portrayed that burn injuries were more common in men than women. Zorita et al. 2013 reported similar findings as in her study $57 \%$ of its subjects were men. This can happen because men have more dangerous activities such as working on electrical installations and working with combustible chemicals. Compared to women, men also have more outdoor activities that increase the chance of burn injuries. ${ }^{21}$

There are some limitations in this study. This study did not assess other factors that might affect burn the patients' QoL, and this also had a small sample size. In spite of the limitations, this study has provided new information about burn patients' QoL in Indonesia.

\section{CONCLUSION}

In conclusion, patients' histories of burn severity, numbers of surgical procedures, and lengths of hospital stay had significant negative correlations with the QoL after treatment in various dimensions. Thus, treatment for the injuries require interactions of various different fields, not only plastic surgery but also psychological and social supports in order to improve the patients' QoL. The assessment of QoL in this study also provides data that can help burn centres to identify the dimensions of QoL after burns, so the burn centres can improve their burn injury management and patient care.

\section{CONFLICT OF INTEREST}

None

\section{ACKNOWLEDGEMENT}

The authors would like to thank to all burn patients who consented to participate in this study.

\section{REFERENCES}

1. Wardhana A, Basuki A, Prameswara ADH, Rizkita DN, Andarie AA, Canintika AF. The epidemiology of burns in indonesia's national referral burn center from 2013 to 2015. Burns: Journal of the International Society for Burn Injuries. 2017; 2(1):67-73.

2. World Health Organization. Burns [Inter- net]. Genvea. 2018. Available from: http:// www.who.int/news-room/fact-sheets/detail/burns/.

3. Kementrian Kesehatan Republik Indonesia. Riset Kesehatan Dasar [Internet]. 2013. Available form: www.depkes.go.id chmidt FM, Santos VL. Prevalence of constipation in the general adult population: An integrative review. Journal of Wound Ostomy \& Continence Nursing. 2014;41(1):70-6; quiz E1-2.

4. Elfiah, U, Riasa N. Epidemiology and Burns Referral in Secondary Burn Unit of Soebandi Hospital, Jember Regency, East Java - Indonesia. In: The 11th Asia Pasific Burn Congress. 2017

5. Tang D, Li-Tsang CWP, Au RKC, Li K, Yi X, Cao $\mathrm{H}$, et al. Functional outcomes of burn patients with ot without rehabilitation in mainland china. Hongkong Journal of Occupational Therapy. 2015; 26: 15-23.

6. Shahid F, Ismali M, Khan S. Assessment of QoL in post burn survivor: a crossectional single-center first validatin study from pakistan. Burns: Journal of the International Society for Burn Injuries. 2018; 2: 35-42.

7. McAleavey AA. Wyka K, Peskin M, Difede J. Physical, functional, psychosocial recovery from burn injury related and their relationship changes over time: a burn model system study. Burns: Journal of the International Society for Burn Injuries. 2018; 44(4): 793-799.

8. Wasiak J, Lee SJ, Paul E, Mahar B, Pfitzer B, Spinks A. Predictors of health status and health-related QoL 12 months after severe burn. Burns: Journal of the International Society for Burn Injuries. 2014; 40: 568574.

9. Edgar D, Dawson A, Hankey G, Phillips M, Rossi LA. Demonstration of the validity of the SF-36 for measurement of the temporal recovery of QoL outcomes in burns survivors. Burns: Journal of the International Society for Burn Injuries. 2010; 36: 10131020.

10. Sjamsuhidajat R, De Jong W. Buku Ajar Ilmu Bedah. Jakarta: EGC, 2010.

11. Odoch R, Atuhairwe C, Titus DAL, Agaba E, Nabankema E. Predictors of length of hos- 
pital stay among burns patients in mulago national referral hospital, kampala-uganda. Journal of Health, Medicine, and Nursing. 2016; 29: 32-39.

12. Johnson LS, Shupp JW, Pavlovich AR, Pezzullo JC, Jeng JC, Jordan MH. Hospital length of stay-does 1\% TBSA really equal 1 day?. Journal of Burn Care \& Research. 2011; 32(1): 9-13.

13. Needham DL. Longer stay in hospital ICU has lasting impact on QoL. 2014. Available from: www.hopkinsmedicine.org.

14. Covinsky KE, Pierluissi E, Johnston CB. Hospitalization-associated disability: "she was probably able to ambulate, but im not sure". Journal of the American Medical Association. 2011; 306(16): 1782-1793.

15. Holavanahalli RK, Helm PA, Kowalske KJ. Long-term outcomes in patients surviving large burns: the musculoskeletal system. Journal of Burn Care \& Research. 2016; 37(4): 243-245.

16. Orwelius L, Willebrand M, Gerdin B, Ekselius L, Fredrikson M, Sjoberg F. Long term health-related QoL after burns is strongly depndent on pre-existing disease and psychological issues and less due to the burn itself. Burns. 2013; 39: 229-235.

17. Bentley A, Andrea P. Burns: Body Image. PACEsetterS. 2011; 8(3): 19-21

18. Amstrong-James L. Coping with changed appearance and body image following a burn injury. Journal of Aesthetic Nursing. 2014; 3(5): 238-241.

19. Candrawati O, Wirasto RT. Risk factor of stroke survivors' quality of life. Jurnal Kedokteran dan Kesehatan Indonesia. 2017; 8(3): 176-182.

20. Jeschkel MG, Gauglitz GG, Kulpl GA, Finnerty CC, Williams FN, Kraft R, et al. Longterm persistance of the pathophysiologic response to severe burn injury. PloS One. 2011; 6(7): e21245.

21. Jain A, Rathore S, Jain R, Gupta ID, Choudhary GL. Assessment of depression and the QoL in burn patients seeking reconstruction surgery. Indian Journal of Burns. 2018; 23: $37-42$ 